\title{
Technical Review of Scheduling and Sequence of Overburden Production PT. Tambang Bukit Tambi
}

\author{
Charina Anggraeni ${ }^{1}$, Shilvyanora Aprilia Rande ${ }^{2}$, Novandri Kusuma Wardana ${ }^{3}$, \\ Hidayatullah Sidiq ${ }^{4}$ \\ \{charina.anggraeni06@gmail.com,shylvyanora@itny.ac.id,novandri.kusuma@itny.ac.id, \\ hidayatullah@itny.ac.id\} \\ Department of Mining Engineering Faculty of Mineral Technology Yogyakarta National Institute of \\ Technology Yogyakarta, Indonesia

\begin{abstract}
Overburden volume at pit 5 PT. Tambang Bukit Tambi site Padang Kelapo is $1,496,925.78 \mathrm{BCM}$ which is located in an area of $10.15 \mathrm{Ha}$ with a disposal distance of $100-300$ meters. The production target based on the available equipment is 1,483 $\mathrm{BCM} /$ hour. The dig-and-load equipment used is the Excavator Komatsu PC-400 LC with equipment productivity of $456.401 \mathrm{BCM} /$ hour with 4 units of equipment, so the productivity of the dig-and-load is $1,825.604 \mathrm{BCM} /$ hour. Then the productivity of the Articulated Dump Truck (ADT) Volvo A40G is 204.248 LCM/hour with 10 units of equipment, so the productivity of the transportation equipment is $2,042.48 \mathrm{LCM} /$ hour. The overburden excavation activity is divided into 4 sequences starting from an elevation of $95-75$ in sequence 1 with an overburden production target of $370,008.5 \mathrm{BCM}$, followed by an elevation of 75-70 in sequence 2 with an overburden production target of $332,933.5 \mathrm{BCM}$, then from elevation 70-65 in sequence 3 with an overburden production target of 391,512 BCM and the last from an elevation of 65-55 in sequence 4 with an overburden production target of 402,472 BCM. For the overburden excavation activity, 4 units of dig-and-load equipment and 10 units of transportation will be used so that the time needed to carry out mining activities from start to finish is around 83 working days.
\end{abstract}

Keywords: Scheduling, Sequence, Overburden Production

\section{Introduction}

PT. Tambang Bukit Tambi is one of the companies engaged in mining in Jambi province. PT. Tambang Bukit Tambi site Padang Kelapo has a Mining Business License Area covering an area of 3,220 Ha located in Maro Sebu subdistrict, Batang Hari regency, Jambi province. Some of these areas have been explored to obtain data on coal reserves in the area and some have been exploited. Before coal mining activities are carried out, it is necessary to schedule (scheduling) and determine the stages (sequence) so that coal mining activities can run effectively and efficiently. The importance of scheduling and determining the stages in coal mine production is based on this research.

Production scheduling serves to create a production plan so that it can run in accordance with a predetermined time. It can be said that production scheduling is done so that the equipment used can work in accordance with the desired production target and in accordance with the specified time. 
The plan of the mining design stage is a form of mining that shows how a mine will be mined from the initial form to the final form. This planned mining design phase will facilitate its mining activities by simplifying all existing volumes in the entire mine into smaller units.

\section{Research Methods}

In carrying out this research, the authors combine the theory of data in the field and interviews so as to obtain an appropriate approach to solving problem. The order of work is:

1. Literature Studies

Literature study is a study of research from existing literature. Literature materials in the form of books and other documentation materials that support research objects. Also planned are work measures that suit the conditions in the field.

2. Research in the Field

Research in the field is conducted through several stages, namely:

a. Field orientation by looking directly at the condition of the field, for example, data collection of the distribution time of units working in the field.

b. Determine the locations that must be observed in accordance with the needs of the data so that the appropriate data can be obtained. For example, determining the initial location of mining activities.

c. Recheck the data taken with the problem formulation that has been created so that the data obtained can be in accordance with the formula that has been discussed.

3. Data Collection

a. Primary data, namely data obtained from observation and collection of data directly in the field, among others data on the circulation time of the dig-and-load equipment, the time of distribution of the transport equipment and the effectiveness of dig-and-load and transport equipment.

b. Secondary data, namely supporting and complementary data, such as available working hours data, number of rainy days of research area, volume overburden, sequence map, sediment model of excavated materials and actual situation map (EOM).

4. Data Processing and Analysis

From the results of data collection that has been taken from the field as well as from literature studies, further processing and analysis of existing data is carried out. The data is processed using the formula:

Cycle Time of Mecanical Equipment

Cycle time is the ability of equipment in conducting a single production cycle. The circulation time of dig-and-load equipment and transport equipment is very influential on the production capability of the equipment, where if the circulation time of each large equipment then the production capability will be smaller. Circulation time can be influenced by road conditions, distance, mechanical condition of equipment, operator skills and others (Indonesianto, 2018). To calculate the cycle time of equipment operating in the field, a stopwatch timer tool is used. The collection of cycle time data of each mechanical equipment is carried out as many as 30 observations. This is intended to meet statistical methods so that the data is close to the truth to then be taken into account against a problem. Collection of cycle time data of each type of equipment operated, carried out on each type of material worked. From the overall data obtained in the field, then averaged based on the "Frequency Distribution Method", using the equation:

$$
\bar{x}=\frac{\sum F i \times X i}{\sum F i}
$$




$$
\begin{aligned}
& K=1+3,322 \log N \\
& C i=\frac{X \max -X \min }{K}
\end{aligned}
$$

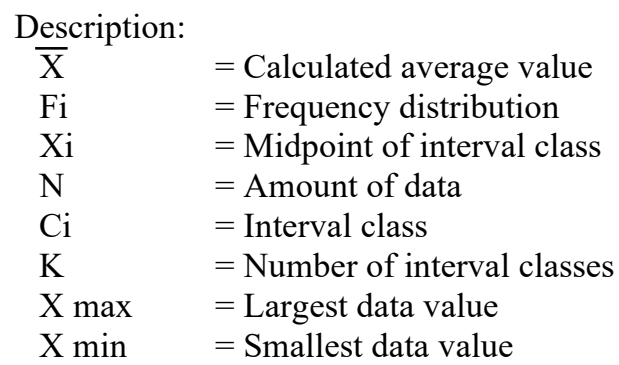

Mechanical Equipment Production

1. Production of Dig-and-Load Equipment

The production capability of excavators is strongly influenced by operator skills, available stock materials and uniformity of grains. The production capability of the dig-and-load equipment can be calculated using the following equation (Indonesianto, 2018):

$$
P=\frac{3600}{C T} \times K B \times F F \times E K
$$

Description:

$$
\begin{aligned}
& \mathrm{P}=\text { Dig-and-load equipment production } \\
& \text { capability }(\mathrm{BCM} / \mathrm{hr}) \\
& \text { CT = Cycle time (seconds) } \\
& \mathrm{KB} \quad=\text { Bucket capacity }\left(\mathrm{m}^{3}\right) \\
& \text { FF } \quad=\text { Bucket fill factor } \\
& \text { EK = Working efficiency (\%) }
\end{aligned}
$$

2. Production of Transport Equipment

To calculate the production capability of the transport equipment, dump truck is considered the combination of loading of the dig-and-load equipment. The ability of transport can be calculated using the following equation (Indonesianto, 2018):

$$
P a=\frac{60}{C T} \times K B \times F F \times S F \times E K \times n
$$

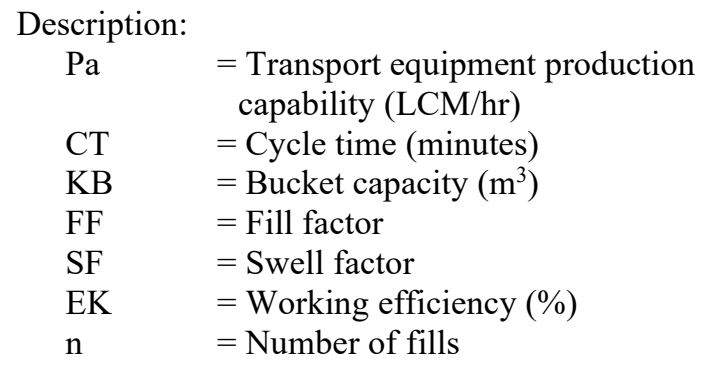

Mine Scheduling

Mine scheduling is one part of mine planning. After modeling geology, block modelling levels, determination of SR or COG, to the design of pit-limit, scheduling becomes very 
important to determine mining activities in the following year. The main purpose of scheduling is to get the NPV (net present value) as optimally as possible. In a similar way, the purpose of scheduling is to make the most of the profits as much as possible with the smallest operating costs (Hustrulid and Kuchta, 1995). To calculate the length of time overburden stripping itself can use the formula:

$$
\text { Stripping time }=\frac{\text { Volume Sequence }}{\text { Productivity equipment }}
$$

\section{Results and Discussion}

A. Volume Overburden

Volume overburden in pit 5 PT. Tambang Bukit Tambi site Padang Kelapo amounted to $1,496,925.78 \mathrm{BCM}$ and coal amounted to $1,144,367.80$ tons in an area $10.15 \mathrm{Ha}$ with a stripping ratio of 1.3. Overburden contained in pit 5 PT. Tambang Bukit Tambi site Padang Kelapo is clay with a density of 2.2 tons $/ \mathrm{m}^{3}$, while coal contained in PT. Tambang Bukit Tambi site Padang Kelapo has a caloric value ranging from 3,000 - 3,500 kcal.

B. Effective Working Time

Working hours available at PT. Tambang Bukit Tambi site Padang Kelapo is 10 hrs/day with the number of shifts that is 1 shift. As for the effective working time in 1 month varies depending on the time of obstacles that exist each month as shown in Table 1 - Table 4.

\begin{tabular}{|c|c|c|c|c|c|}
\hline & DESCRIPTION & Plan & & Unit & Monthly \\
\hline \multicolumn{6}{|c|}{ Total Days and Shift : } \\
\hline & Calendar Days & & & days & 30 \\
\hline & Over Shift & & & days & 0 \\
\hline & Ramandhan Day & & & days & 7 \\
\hline & Holiday & & & days & 0 \\
\hline & Friday Praying (hr/week) & & & days & 4 \\
\hline & Safety Talk Schedule & & & days & 2 \\
\hline & Shifts/day & & & & 1 \\
\hline & Hrs/shift & & & & 10 \\
\hline \multicolumn{3}{|c|}{ Machine Onhand Hours } & & (hrs) & 300 \\
\hline \multirow{2}{*}{\multicolumn{3}{|c|}{ Lost Time }} & (Lost) & (hrs) & 50,5 \\
\hline & & & $\%$ Lost & $\%$ & $16,83 \%$ \\
\hline 1. & Rainy & 6 & days & (hrs) & 6 \\
\hline 2. & Slippery & $50 \%$ & $\%$ of rainy & (hrs) & 3 \\
\hline 3. & Over Shift & 0 & hrs/day & (hrs) & - \\
\hline 4. & Fasting (Ramadhan) & 1 & hrs/day & (hrs) & 7 \\
\hline 5. & Meal and Rest & 1 & hrs/day & (hrs) & 30 \\
\hline 6. & Holiday & 0 & day & (hrs) & - \\
\hline 7. & Shift Change & 0 & hrs/day & (hrs) & - \\
\hline 8. & Safety Talk & 15 & min/week & (hrs) & 0,5 \\
\hline 9. & Friday Praying (hr/week) & 1 & hrs/week & (hrs) & 4 \\
\hline 10. & Working Hours/Month & & & & 249,5 \\
\hline
\end{tabular}

Table 2. Effective Working Time May 2020

\begin{tabular}{lrrr}
\hline \multicolumn{1}{c}{ DESCRIPTION } & Plan & Unit & Monthly \\
\hline Total Days and Shift : & & & \\
\hline Calendar Days & days & \\
\hline Over Shift & days & \\
\hline Ramandhan Day & days & 23 \\
\hline Holiday & days & 0 \\
\hline
\end{tabular}




\begin{tabular}{|c|c|c|c|c|}
\hline Friday Praying (hr/week) & & & days & 5 \\
\hline Safety Talk Schedule & & & days & 2 \\
\hline Shifts/day & & & & 1 \\
\hline Hrs/shift & & & & 10 \\
\hline Machine Onhand Hours & & & (hrs) & 310 \\
\hline Lost Time & & (Lost) & $(h r s)$ & 85,5 \\
\hline & & $\%$ Lost & $\%$ & $27,58 \%$ \\
\hline Rainy & 4 & days & $(h r s)$ & 4 \\
\hline Slippery & $50 \%$ & $\%$ of rainy & $(h r s)$ & 2 \\
\hline Over Shift & 0 & $h r s / d a y$ & $(h r s)$ & - \\
\hline Fasting (Ramadhan) & 1 & hrs/day & $(h r s)$ & 23 \\
\hline Meal and Rest & 1 & hrs/day & $(h r s)$ & 31 \\
\hline Holiday & 2 & day & $(h r s)$ & 20 \\
\hline Shift Change & 0 & hrs/day & $(h r s)$ & - \\
\hline Safety Talk & 15 & min/week & $(h r s)$ & 0,5 \\
\hline Friday Praying (hr/week) & 1 & hrs/week & $(h r s)$ & 5 \\
\hline 10. Working Hours/Month & & & & 224,5 \\
\hline
\end{tabular}

Table 3. Effective Working Time June 2020

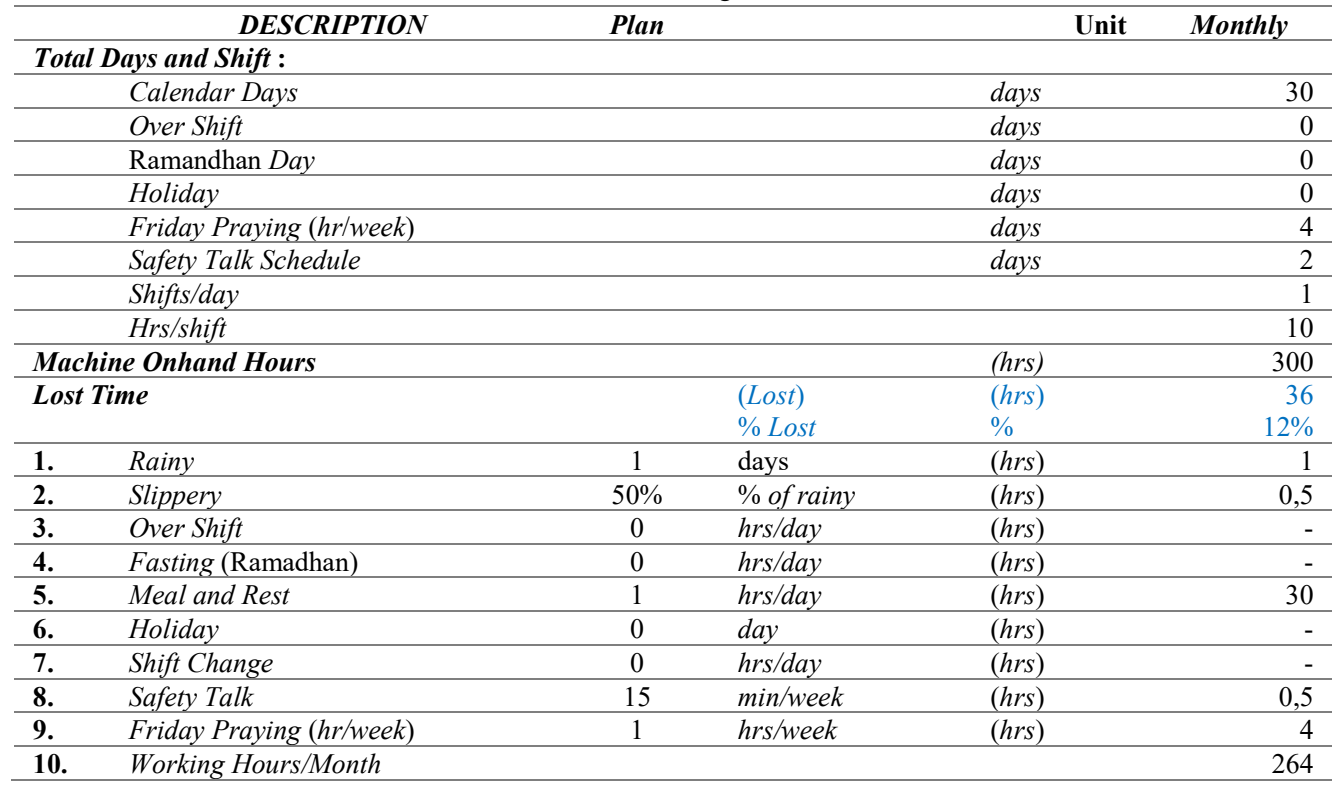

Table 4. Effective Working Time July 2020

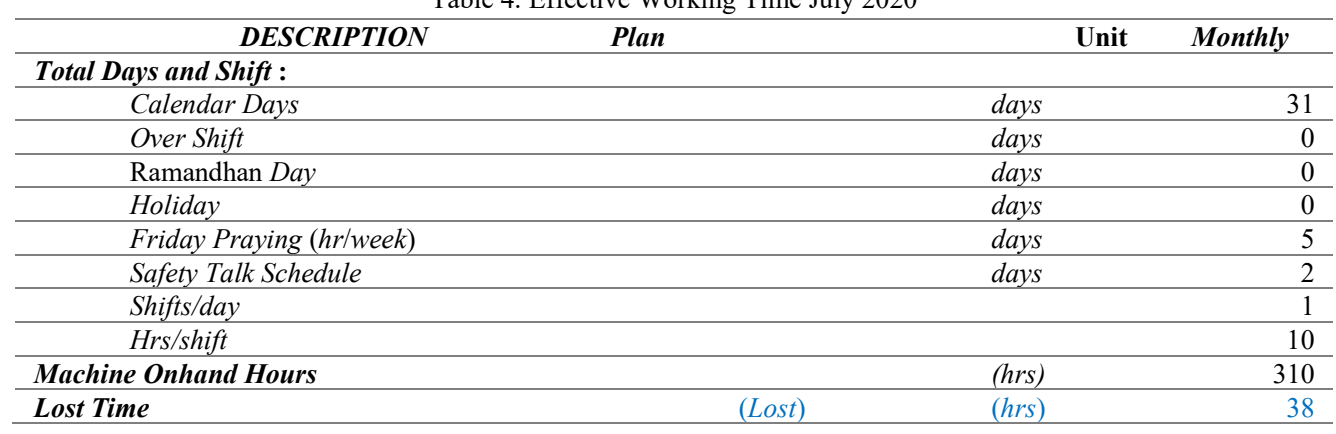




\begin{tabular}{|c|c|c|c|c|c|}
\hline & & & $\%$ Lost & $\%$ & $12,26 \%$ \\
\hline 1. & Rainy & 1 & days & $(h r s)$ & 1 \\
\hline 2. & Slippery & $50 \%$ & $\%$ of rainy & $(h r s)$ & 0,5 \\
\hline 3. & Over Shift & 0 & $h r s / d a y$ & $(h r s)$ & - \\
\hline 4. & Fasting (Ramadhan) & 0 & hrs/day & $(h r s)$ & - \\
\hline 5. & Meal and Rest & 1 & hrs/day & $(h r s)$ & 31 \\
\hline 6. & Holiday & 0 & day & $(h r s)$ & - \\
\hline 7. & Shift Change & 0 & hrs/day & $(h r s)$ & - \\
\hline 8. & Safety Talk & 15 & min/week & $(h r s)$ & 0,5 \\
\hline 9. & Friday Praying (hr/week) & 1 & hrs/week & $(h r s)$ & 5 \\
\hline 10. & Working Hours/Month & & & & 272 \\
\hline
\end{tabular}

C. Estimated Productivity of Dig-and-Load Equipment

The estimate for excavator productivity Komatsu PC-400 LC is approximately 456,401 $\mathrm{BCM} /$ hour or $136,920.3 \mathrm{BCM} / \mathrm{month}$. Because the equipments used there are 4 units, the production is $547,681.2 \mathrm{BCM} / \mathrm{month}$.

D. Stages of Mining Activities

Coal mining at PT. Tambang Bukit Tambi site Padang Kelapo is planned to start from the west side to the east side. The mining site is a relatively narrow area, with such conditions it is planned that the disposal of overburden material is carried out in the pit. In pit 5 this will be divided into 4 sequences that are adjusted to the production scheduling (Figure 1).

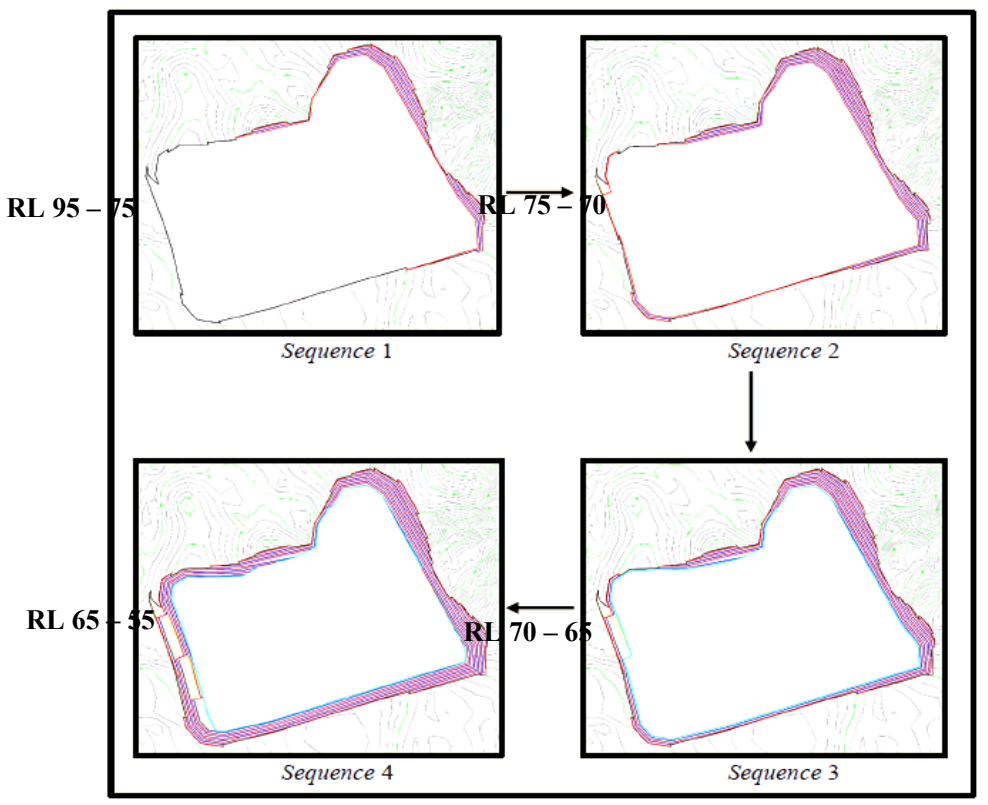

Fig 1. Sequence of Overburden Mining

This overburden excavation activity starts from elevation $95-75$ on sequence 1 , followed by sequence 2 at elevation 75-70, then sequence 3 at elevation 70-65 and finally sequence 4 at elevation 65-55. All overburden materials will be transported and stockpiled at disposal located on the west side of the pit. For this overburden excavation activity will be used 4 units of digging equipment and 10 units of transport. 
E. Production Scheduling

Overburden stripping activities at PT. Tambang Bukit Tambi site Padang Kelapo will be conducted using Excavator Komatsu PC-400 LC and Articulated Dump Truck (ADT) Volvo A40G. The planned overburden production target in pit 5 is $1,483 \mathrm{BCM} /$ hour with astripping ratio of 1.3. Based on the production target, it is estimated that the length of overburden stripping time on pit 5 is for 83 working days. For more details on the production target of overburden pit 5 PT. Tambang Bukit Tambi site Padang Kelapo is shown in Table 5 below.

\begin{tabular}{cc} 
Table 5. Overburden Production Target in Pit 5 PT. Tambang Bukit Tambi site Padang Kelapo \\
\hline Month & Production Target (BCM) \\
\hline $\mathbf{1}$ & $370,008.5$ \\
\hline $\mathbf{2}$ & $332,933.5$ \\
\hline $\mathbf{3}$ & 391,512 \\
\hline $\mathbf{4}$ & 402,472 \\
\hline Total & $1,496,926$ \\
\hline
\end{tabular}

1. First Month Overburden Stripping

In the first month of overburden stripping, Excavator Komatsu PC-400 LC will be served with 10 ADT Volvo A40G. In the first month, mining activities will start from an elevation of 95-75 with a total volume of $397,221.89$ BCM and takes 22 working days.

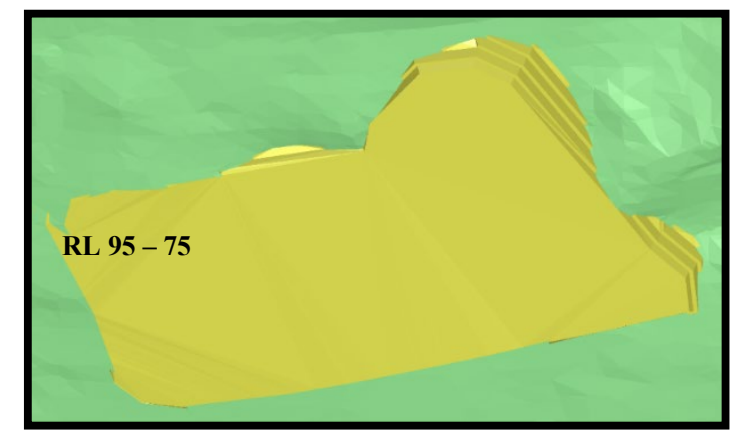

Fig 2. Sequence 1

2. Second Month Overburden Stripping

In the second month of overburden stripping, Excavator Komatsu PC-400 LC will be served with 10 ADT Volvo A40G. In the second month, mining activities will start from an elevation of 75-70 with a total volume of 418,276.18 BCM and takes 23 working days.

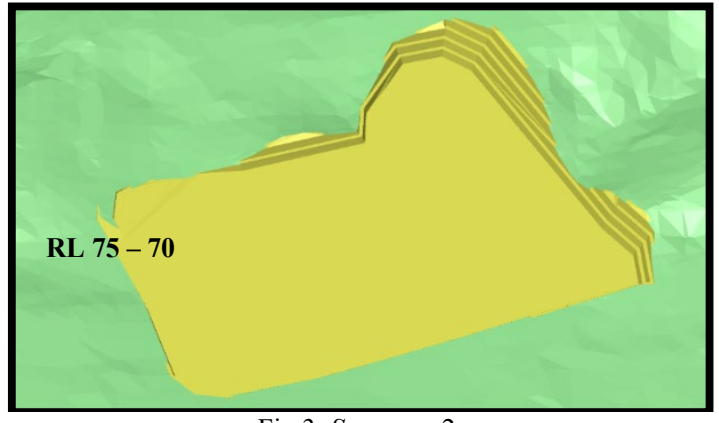

Fig 3. Sequence 2

3. Third Month Overburden Stripping 
In the third month of overburden stripping, Excavator Komatsu PC-400 LC will be served with 10 ADT Volvo A40G. In the third month, mining activities will start from an elevation of 70-65 with a total volume of 410,962.89 BCM and takes 23 working days.

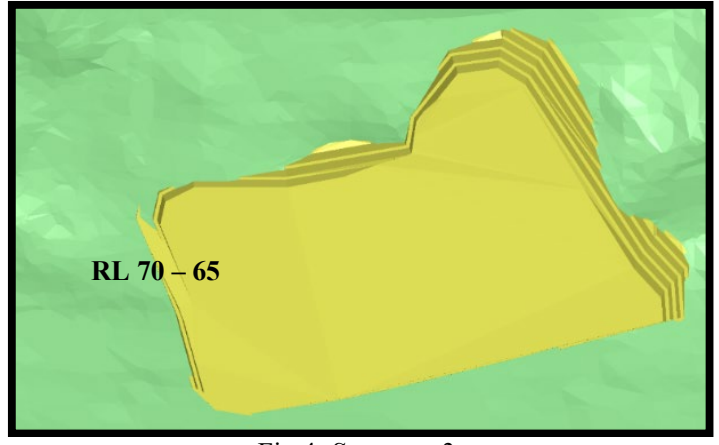

Fig 4. Sequence 3

4. Fourth Month Overburden Stripping

In the fourth month of overburden stripping, Excavator Komatsu PC-400 LC will be served with 10 ADT Volvo A40G. In the fourth month, mining activities will start from an elevation of $65-55$ with a total volume of $270,464.85$ BCM and takes 15 working days.

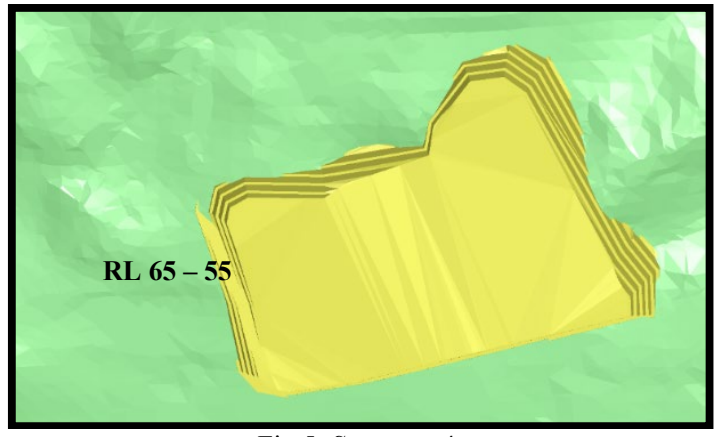

Fig 5. Sequence 4

From the discussion above, the total estimated time for overburden stripping is takes 22 days +23 days +23 days +15 days $=\mathbf{8 3}$ working days with the total volume of overburden that must be peeled as much as $\mathbf{1 , 4 9 6 , 9 2 5 . 8 1 ~ B C M}$.

The amount of equipment production must be sufficient for the size of the production target that has been set. The amount of equipment production against the overburden production target is shown in Table 6.

\begin{tabular}{ccccc} 
Month & $\begin{array}{c}\text { Table 6. Comparison of Equipment Production Size to Overburden Production Target } \\
\text { Production Target } \\
\text { (BCM) }\end{array}$ & $\begin{array}{c}\text { Excavator } \\
\text { Production/Unit (BCM) }\end{array}$ & $\begin{array}{c}\text { Number of } \\
\text { Excavators }\end{array}$ & $\begin{array}{c}\text { Excavator Production } \\
\text { (BCM) }\end{array}$ \\
\hline $\mathbf{1}$ & $370,008.5$ & $136,920.3$ & 4 & $547,681.2$ \\
\hline $\mathbf{2}$ & $332,933.5$ & $136,920.3$ & 4 & $547,681.2$ \\
\hline $\mathbf{3}$ & 391,512 & $136,920.3$ & 4 & $547,681.2$ \\
\hline $\mathbf{4}$ & 402,472 & $136,920.3$ & 4 & $547,681.2$ \\
\hline
\end{tabular}

From the table above can be seen that the productivity of the equipment can meet the desired production target every month. 
In the activity of stripping activities of overburden at PT. Tambang Bukit Tambi site Padang Kelapo used pair of Excavator Komatsu PC-400LC with bucket capacity of $2.2 \mathrm{~m}^{3}$ and Articulated Dump Truck (ADT) Volvo A40G with a body capacity of $24 \mathrm{~m}^{3}$. The match factor between the use of the two equipments is shown in the formula below.

$$
\begin{gathered}
M F=\frac{\text { Number of } A D T \times \text { Number of fills } \times C T \text { Excavator }}{\text { Number of Excavators } \times C T A D T} \\
M F=\frac{10 \text { unit } \times 5 \times 0,41 \text { minutes }}{4 \text { unit } \times 4,18 \text { minutes }} \\
M F=1,23
\end{gathered}
$$

From the above results can be known for the stripping activities of overburden has a harmony of equipments (match factor) of 1.23 with the number of excavators as much as 4 units and articulated dump truck (ADT) as much as 10 units. This indicates that the excavator is fully working while the dump truck has a waiting time. This is considered effective because the digand-load equipments will always be served to the maximum by the dump truck so that the desired production target can be met.

\section{Conclusion}

Based on the above discussion on the scheduling of production stripping overburden at PT. Tambang Bukit Tambi site Padang Kelapo, then it can be concluded: Volume overburden in pit 5 PT. Tambang Bukit Tambi site Padang Kelapo amounted to 1,496,925.78 BCM which is in an area of $10.15 \mathrm{Ha}$ based on exploration data that has been done. Productivity of Excavator Komatsu PC-400 LC of 1,825,604 BCM/hour or 18,256.04 BCM/day or 547,681.2 BCM/month for each equipment. Then for productivity of Articulated Dump Truck (ADT) Volvo A40G of $204,248 \mathrm{LCM} /$ hour or 2,042.48 LCM/day or 61,274.4 LCM/month for each equipment. As for the production target of stripping overburden of $1,483 \mathrm{BCM} /$ hour which for the desired production target has been achieved. Time required for stripping activities overburden in pit 5 PT. Tambang Bukit Tambi site Padang Kelapo is takes 83 working days divided into 4 sequences. Scheduling production of overburden in pit 5 PT. Tambang Bukit Tambi site Padang Kelapo in the first month amounted to $370,008.5 \mathrm{BCM}$, the second month amounted to $332,933.5 \mathrm{BCM}$, the third month amounted to $391,512 \mathrm{BCM}$ and for the fourth month amounted to 402,472 BCM. Advice that can be given to mining activities at PT. Tambang Bukit Tambi site Padang Kelapo is as follows: It is necessary to have a good monitoring system in the activity of scheduling overburden so that the predetermined production targets can be met. Perform maintenance on heavy equipment, both excavators and mining activities at PT. Tambang Bukit Tambi site Padang Kelapo is running effectively. Appeal to all employees to work on time according to a predetermined schedule in order to reduce working hours and to always maintain work health and safety.

\section{References}

[1.] Hartman, H.L., 1987, "Introductory Mining Engineering", The University of Alabama Tuscaloosa, Alabama.

[2.] Hustrulid, W., and Kuchta, M., 1995, "Open Pit Mine Planning \& Design 2nd Edition Vol 1", Fundamentals, Balkema/Rotterdam/Brockfield. 
[3.] Hustrulid, W., and Kuchta, M., 1995, "Open Pit Mine Planning \& Design 3rd Edition Vol 1", Fundamentals, Balkema/Rotterdam/Brockfield.

[4.] Indonesianto, Y., 2018, "Pemindahan Tanah Mekanis", Department of Mining Engineering, Yogyakarta National Institute of Technology, Yogyakarta.

[5.] Indonesianto, Y., and Sidiq, H., 2019, "Perencanaan Tambang Terbuka", Department of Mining Engineering, Yogyakarta National Institute of Technology, Yogyakarta.

[6.] Prabowo, B.A., 2020, "Rancangan Teknis Penambangan Batubara Jangka Pendek Pit 9-10 di PT. Madhani Talatah Nusantara Site Project Asam Asam Tanah Laut Kalimantan Selatan”, Mining Insight Vol. 01, No. 01, Maret 2020: 11-19.

[7.] Prodjosumarto, P., 1993, "Diktat Kuliah Pemindahan Tanah Mekanis”, Department of Mining Engineering, Bandung Institute of Technology, Bandung.

[8.] Sidiq, H., 2016, "Penentuan Pit Limit Penambangan Batubara Dengan Metode Lerchs-Grossmann Menggunakan 3DMine Software”, Jurnal Kurvatek Vol. 1, No. 2, November 2016: 67 - 72.

[9.] Sidiq, H., 2018, "Perancangan Design Tambang", Department of Mining Engineering, Yogyakarta National Institute of Technology, Yogyakarta. 